\title{
INDUSTRIAL ENGINEERING
}

DOI https://doi.org/10.30525/978-9934-588-79-2-1.29

\section{DIRECTION OF COMPLEX SOLUTION \\ OF THE CANAL CONSTRUCTION ISSUE \\ FROM MOLOCHNYI ESTUARY TO THE AZOV SEA}

\author{
Bondarenko A. O. \\ D.Sc. (Tech.), Associate Professor,
}

Professor at the Department of engineering and design in machinery industry

National Technical University "Dnipro Polytechnic»

Medvedieva O. O.

Ph.D. (Tech.),

Senior Researcher at the Department of Geodynamic Systems

and Vibration Technology

Institute of Geotechnical Mechanics named

by N. Poljakov of National Academy of Sciences of Ukraine

Tatarko L.G.

Ph.D. (Tech.),

Associate Professor at the Department of Power Engineering

Ukrainian State University of Chemical Technology

Dnipro, Ukraine

The Molochny estuary is one of the most valuable wetlands of the Azov Sea, which is included in the Ramsar Convention on Wetlands of International Importance. According to the physical and geographical zoning of Ukraine, the Molochny estuary belongs to the Pontic-Caspian steppe region of the Black Sea southern steppe province. This area is located in the Zaporizhia region within the Yakymivsky, Pryazovsky and Melitopolsky districts. The estuary is $32 \mathrm{~km}$ long, its width running up to $8 \mathrm{~km}$ and its depth up to $3 \mathrm{~m}$, its area is around $170 \mathrm{~km}^{2}$. The estuary is separated from the Sea of Azov by the Peresyp Split with an artificially created channel. Lately the connecting channel of the Molochny estuary practically has been out of use.

From a historical point of view, the Molochny Estuary, depending on the degree of its connection with the Sea of Azov, has four characteristic states of its ecosystem [1]: 
- open (the bay of the Sea of Azov during period up to the XV century);

- closed (the salt lake during period from the end of the 15th century to 1943);

- semi-open (the connection with the Sea of Azov that happened due to a wide and well-functioning strait or several straits during the period from 1943 to 1972);

- semi-closed (the connection with the Sea of Azov happened due to one single strait, which operates periodically or to a limited extent during the period from 1972 to the present).

It ihas been established that each of these states had its specific hydrological, hydrochemical and hydrobiological characteristics. However, among them a semi-open state of the estuary ecosystem is characterized by the stability of hydrochemical parameters and hydrobiological regime with the recorded maximum species diversity of fish and the highest fish productivity [1].

According to the stated above, the construction and maintenance of an artificial canal connecting the Sea of Azov with the Molochny Estuary will guarantee the stable existence of the estuary's hydrological system. While the development of economically feasible technology for such work is an important and relevant scientific and technical problem. This problem can be solved by developping cost-effective methods and means for the extraction, transportation and processing of minerals from the body of the spit during the construction and maintenance of the connecting channel.

Taking into account the known mining and geological conditions of the work area obtained from open sources, for the extraction and transportation of raw materials it is adviced to use the technology of floating dredgers, refueling, semi-submersible and stationary slurry pipelines.

The variety of dredgers design and their technological parameters manufactured by industry, including Ukrainian enterprises, allows us to choose equipment that can solve a specific problem with a minimum cost of mining operations. For instance, the use of dredgers with submersible ground pumps manufactured by well-known companies such as Dragflow, Warman, Metso Minerals, Habermann, etc., compared with deck and bilge ground pumps, will reduce the cost of extraction and transportation of soil by increasing the pulp concentration. Thus, according to the source [2] the average concentration of pulp for incoherent soils for the traditional design of suction pipes is about $10 \%$, while during the submersible location of the ground pump the manufacturers state an increase in the average concentration of pulp to $30 \%$. 
The greatest interest in the development of complex technological solutions for the construction and maintenance of the connecting channel between Azov Sea and the Molochny Estuary lies in solving the problem of mineral processing by performing construction and dredging works. The extracted rock mass can be processed, for example, into sand and feed shell, according to the relevant standards: Sand as in National Standards of Ukraine of Buildings and Constructions 2.1-23-95, National Standards of Ukraine of Buildings and Constructions 2.7-32-95, National Standards of Ukraine of Buildings and Constructions 2.7-29-95; Feed shell as in All-Union state standard 26826-86.

In this regard, there is the question of developing the means and methods for obtaining marketable products directly on the site of construction and dredging.

Almost always the process of enrichment of nonmetallic building materials involves the separation from sand of large inclusions, small dusty and clay impurities, lump clay, vegetable inclusions and shells. Since 2004 the Institute for the Design of Mining Enterprises, working under National Mining University (Dnipropetrovsk, Ukraine) has repeatedly solved the problem of processing rock mass into building materials with a hydromechanized method of extraction. For this purpose known and brand new technological solutions and devices were used, such as: the alluvial maps; the motionless screens ; the movable screens; the hydraulic classifiers; the decanting tanks.

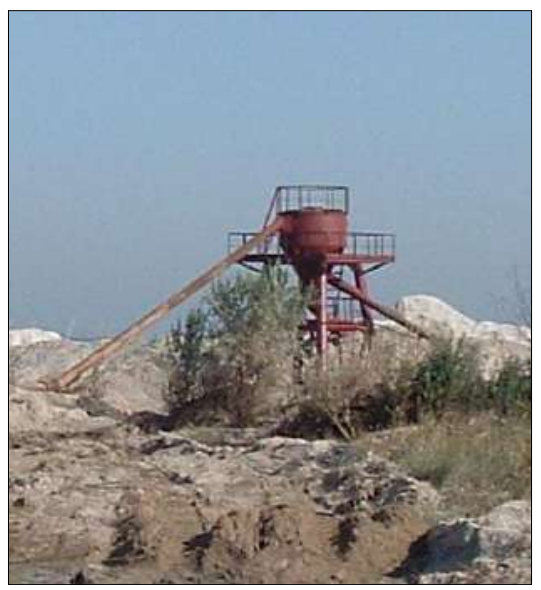

Fig. 1. Conical screen for shell separation 
When choosing the enrichment equipment for processing sand-shell mass, which is extracted using floating suction shells, we must take into account the possibility of lack of centralized energy, water and pneumatic supply of the processing area. So in this case we should use the screens with a fixed sieving surface : bar, arc and conical ones (Fig. 1). In such screens, the release of gravel, lump clay, debris, shells, etc. from the original pulp is performed due to the interaction with the sieving surface of the flow of a heterogeneous mixture, which received kinetic energy as a result of the operation of the ground pump of the suction projectile [4-7].

The simplest in terms of design, of the screen types stated above is an inclined bar screen, the efficiency of which is around 85-95\%, and it increases with the decrease of pulp concentration [3]. The bar screens are installed at an angle to the horizon assembled grids. The material that is loaded on the upper end of the grid moves along under the action of the kinetic energy of the pulp flow and gravity. In this case, the fine sand fraction falls through the cracks and the rest moves down the surface.

The disadvantages of an inclined bar screen include rapid wearinf out of the sieve, which is the result of high flow rates of pulp that falls on them. Despite this disadvantage, they are often used for separation from natural sand materials and screenings of crushing large fractions of +3 up to +5 mm (Fig. 2).

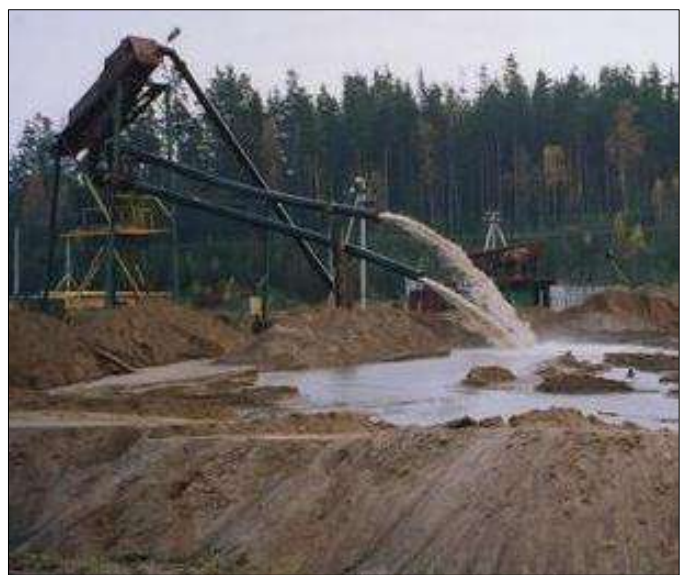

Fig.2 Inclined screen

The design of an inclined bar screens, adapted for work directly at the rock mass extraction site, can be executed in the form of the mobile module 118 
and due to the simplicity of its design does not demand special maintanance and high qualification of service personnel (fig. 3).

A more advanced processing of the sand-shell mixture is also possible through the use of special enriching separator operating in combination with a dredger. [8].

Of all the variety of devices on the market that implement the hydraulic method of processing nonmetallic sands, mining companies use enriching systems based on the following separators: washing and drainage pump company STICHWEH (Germany), sand classification systems Fines Master Powerscreen (the United Kingdom) and CDE (Ireland), direct-flow hydraulic classifier like GKD (Russia), gravitational sand washing of MPG (Ukraine), spiral classifier, etc.

Such complexes include three stages of separation of rock mass:

- firstly, the large inclusions, such as gravel, lump clay, plant remains, and shells, are separated from the sand. This problem is solved by using movable and motionless screens;

- secondly, it comes to organizing the process of washing of clay and fine particles from sand. For this purpose we use the hydrocyclones, the troughs, the vertical and horizontal hydraulic classifiers ;

- the last stage involves dehydration and storage of marketable products, while the clay and fine fraction is further removed from it. The dehydration process is traditionally performed with the use of scoop-dewatering wheels, vibrating screens, bucket elevators, auger feeders. To store the produce we use the conveyor belt or the hydraulic dumps.



Fig. 3. Use of an inclined screen for sand separation

The main criterion for the adoption of the mineral processing technological scheme lies in energy consumption or its cost, reduced to a unit of 
output. The most rational solution of each of the technological schemes is the one that provides the minimum specific energy consumption, and, as a consequence, the minimum unit cost.

When it comes to the considered technologies, the energy capacity can be significantly reduced by the replacing steel pipes with the polyethylene pipes. In this case, to calculate hydraulic slope and critical speed one should use the followilng formulas $[9,10]$ :

$$
i=\sigma i_{c}, \quad V_{c r}^{\prime}=V_{c r} \sqrt[3]{\frac{\Delta}{\Delta^{\prime}}}, \quad \sigma=\frac{0.562}{c^{0.253}},
$$

In wich $i$ stands for the hydraulic slope in a polyethylene pipeline, $\mathrm{m}$ water standard cubic metre; $\sigma$ is the scaling factor ; $C_{\text {is slurry volume }}$ concentration; $i_{c}$ is the hydraulic slope in a steel pipeline, $\mathrm{m}$ water standard cubic metre ; $V_{c r}^{\prime}$ is the critical speed in a polyethylene pipe, mps; $V_{c r}$ is the critical speed in a steel pipe according to the used technique, mps; $\Delta$ is the absolute inner surface irregularity of the steel pipe, $\mathrm{m} ; \Delta^{\prime}$ is is the absolute inner surface irregularity of the polyethylene pipe, $\mathrm{m}$.

Conclusions. The construction and maintenance of the connecting canal between Azov Sea and Molochny estuary should be considered from the point of view of the contractor's interest and motivation to perform construction and dredging works by processing the extracted rock mass into construction sand and feed shell. In this case, to comply with the quality of marketable products according to current standards, it is necessary to use modern rational enrichment technologies.

\section{References:}

1. Demchenko V.O. Ixthiofauna and indicators of water quality in a milk estuary in conjunction with ribogospodarskim vikorystannya waters: Abstract Dis. ... Cand. tech. sciences: 03.00.10.

2. Bondarenko A.A. Improvement of erosion systems for suction dredgers: monograph. D. : National Mining University, 2012. 105 p.

3. Bondarenko A.O. Girnichi machines for critical servicing robots: Navch. Posibnik. - Dnipro: DVNZ "National State University", 2017. $123 \mathrm{p}$.

4. Bondarenko A.O. Girnichi machines for submarine girnichi robots: Navch. Posibnik. - Dnipropetrovsk, RVV NSU of Ukraine, 2003. 90 p.

5. Bondarenko A. A. Substantiation of the method of enrichment of quartz sands during their hydromechanized mining. Mineral processing. 2007. Vip. 29 (70) -30 (71). P. 70-84. 
6. Bondarenko A.O., Ponomarenko G.I. Stagnation of stolen roars during the development of genera of non-difficult problems. Naukovy Visnik NMU. 2009. № 3. P. 78-82.

7. Bondarenko A.A. On the substantiation of rational technology for the beneficiation of fine-grained materials. Mineral processing. 2008. 33 (74).

8. Bondarenko, A. A. Theoretical bases of pulp suction process in the shallow dredge underwater face. Naukovy Visnik NMU. 3, pp. 22-29. DOI: $10.29202 /$ nvngu/2018-3/4.

9. O. Medvedeva. Development and exploitation of storages of enrichment process wastes as anthropogenic deposits. Theoretical and practical solutions of mineral resources mining. London: Taylor \& Francis Group, 2015 567-573

10. Farzad Fatehi, Yevhen Semenenko, Olha Medvedieva, Larysa Tatarko and Olexander Haminich (2020). Argumentation for critical parameters and operating modes in the process of underwater mining of placers. E3S Web of Conferences, 168, 00043. https://doi.org/10.1051/ e3sconf $/ 202016800043$

DOI https://doi.org/10.30525/978-9934-588-79-2-1.30

\title{
DETERMINATION OF THE BOUNDARY SHEAR STRESS OF THE TWO-PHASE SYSTEM ON THE EXAMPLE OF A PHARMACEUTICAL MIXTURE
}

\author{
Dolomakin Y. Y. \\ Ph.D, Associate Professor, \\ Department of Machines and Apparatuses \\ for Food and Pharmaceutical Productions \\ Educational and Scientific Institute of Technical Engineering \\ by name of Academician I. S. Hulyi of the National University \\ of Food Technologies \\ Kyiv, Ukraine
}

To determine the optimal conditions for controlling the properties of dispersed structures, it is necessary to establish the mechanism and kinetics of the formation and destruction of the spatial structural grid, that is, the kinetics of the interaction of the solid phase of the mixture, water and gase- 